\title{
Invasion of Rubus praecox (Rosaceae) is promoted by the native tree Aristotelia chilensis (Elaeocarpaceae) due to seed dispersal facilitation
}

\author{
La invasión de Rubus praecox (Rosaceae) es promovida por el árbol nativo \\ Aristotelia chilensis (Elaeocarpaceae) debido a la facilitación de la dispersión de \\ semillas
}

\author{
MARCEL REJMÁNEK
}

Department of Evolution and Ecology, University of California, Davis, CA 95616, USA.

mrejmanek@ucdavis.edu

\begin{abstract}
Seed dispersal facilitation among plant neighbours can be defined as an increase in the number, distances, and/or places reached by a plant's seeds that is due to the presence of co-fruiting plant neighbours with which it shares seed dispersers. Many cases of this phenomenon have been described among native species and some also among introduced invasive species. Moreover, facilitation of native species recruitment by non-native fleshy-fruiting trees has been reported. Surprisingly, seed dispersal facilitation of exotic species by native species is either less common or has not been properly documented so far. Casual observation of secondary vegetation in La Araucanía Region, Chile, suggests that more individuals of exotic fleshy-fruiting bird-dispersed Rubus praecox (Rosaceae) are established under the native fleshy fruiting bird-dispersed subdioecious tree Aristotelia chilensis (Elaeocarpaceae) than under other native dry-fruiting tree species in the same areas. To assess whether these observation-suggested differences are statistically significant, two plots were sampled for interspecific associations between Rubus and Aristotelia and between Rubus and the most common dry-fruiting monoecious tree-Lomatia hirsuta (Proteaceae). The first important conclusion from this study is that invasive Rubus is substantially more common under both focal tree species than in open grasslands. Second, Rubus is associated more strongly with fleshy-fruiting Aristotelia than with dry-fruiting Lomatia in this landscape. Additionally, the frequency of Rubus is higher under Aristotelia fruiting (female or hermaphroditic) trees. Management implications are discussed.
\end{abstract}

KeYwords: Frugivory, plant invasion, seed dispersal, South-Central Chile.

\section{RESUMEN}

La facilitación de la dispersión de las semillas entre plantas vecinas se puede definir como un incremento en el número, distancia, y/o lugares alcanzados por las semillas de una planta debido a la presencia de plantas vecinas que co-fructifican y con las que la especie comparte dispersores de semillas. Se han descrito muchos casos de este fenómeno entre especies nativas y algunas también entre especies introducidas invasoras. Además, se ha informado de la facilitación del reclutamiento de especies nativas por árboles no-nativos de fruto carnoso. Sorprendentemente, la facilitación de la dispersión de semillas de las especies exóticas por especies nativas es menos común, o no ha sido debidamente documentada hasta el momento. La observación casual de la vegetación secundaria en la Región de la Araucanía, Chile, sugiere que más individuos de la especie exótica Rubus praecox (Rosaceae), cuyos frutos carnosos son dispersados por las aves, se establecen bajo el árbol nativo Aristotelia chilensis (Elaeocarpaceae) que también posee frutos carnosos, que bajo otra especies de árboles nativos con frutos secos en las mismas áreas. Para evaluar si las diferencias de observación sugeridas son estadísticamente significativas, se muestrearon dos parcelas para estudiar las asociaciones interespecíficas entre Rubus y Aristotelia y entre Rubus y el árbol más común de frutos secos -Lomatia hirsuta (Proteaceae). La primera conclusión importante de este estudio es que la invasora Rubus es mucho más común bajo ambas especies focales que en pastizales abiertos. En segundo lugar, Rubus se asocia más fuertemente con Aristotelia subdioica con frutos carnosos que con la especie monoica de frutos secos Lomatia,en este paisaje del sur de Chile. Además, la frecuencia de Rubus es mayor bajo árboles productores de frutos de Aristotelia (femeninos o hermafroditas). Se discuten las implicaciones para la gestión de la especie invasora.

Palabras clave: Centro-sur de Chile, dispersión de semillas, frugivoría, invasión de plantas.

\section{INTRODUCTION}

In ecological literature, spontaneously reproducing and spreading human-introduced species are called "invasive" (Richardson et al. 2000, Pyšek et al. 2004, Simberloff \&
Rejmánek 2011). Most of the invasive plant species are incorporated into native, mostly disturbed, plant communities without any noticeable impacts. However, some plant invaders may have substantial impacts on native ecosystems and their biodiversity (Rejmánek et al. 2013). 
Populations of resident plant species, either native or non-native, can facilitate establishment and invasion of nonnative plant species (Maron \& Connors 1996, Calloway 2007, Foxcroft \& Rejmánek 2007, Tecco et al. 2007, Cavieres et al. 2008, Madrigal-Gonzales et al. 2013, Flory \& Bauer 2014). One important category of non-native plant facilitations is seed dispersal facilitation. Seed dispersal facilitation among plant neighbours can be defined as an increase in the number, distances, and/or places reached by a plant's seeds that is due to the presence of co-fruiting plant neighbours with which it shares seed dispersers (Carlo 2005). This is sometimes called "shared attraction" (Bronstein 2009). Many cases of this phenomenon have been described among native species (Vieira et al. 1994, Clark et al. 2004, Carlo 2005, Carlo \& Aukema 2005, García et al. 2007, Von Zeipel \& Eriksson 2007, Carlo \& Tewksbury 2014) and some also among introduced invasive species (Tecco et al. 2006, 2007, White \& Vivian-Smith 2011). Moreover, facilitation of native species recruitment by non-native fleshy-fruiting trees has been reported (Neilan et al. 2006, Foster \& Robinson 2007, Bernes et al. 2008). Surprisingly, seed dispersal facilitation of exotic species by native species is either less common or has not been properly documented so far. Some dispersal facilitation of exotic Ligustrum lucidum (Oleaceae) by native Guioa semiglauca (Sapindaceae) was reported from Australia, but this was three times smaller than dispersal facilitation of $L$. lucidum by exotic Cinamonum camphora (Lauraceae) (White \& Vivian-Smith 2011).

Casual observation of secondary vegetation (mostly active or abandoned pastures) in La Araucanía Region, Chile, suggests that more individuals of exotic fleshy-fruiting birddispersed Rubus praecox Bertol. (Rosaceae, hereafter Rubus) are established under native fleshy fruiting bird-dispersed tree Aristotelia chilensis (Molina) Stuntz (Elaeocarpaceae, hereafter Aristotelia) than under other native dry-fruiting tree species in the same areas. The fruiting periods of Aristotelia and Rubus partly overlap (at least the first two weeks of February). The major dispersal agents of both species seem to be the austral thrush (Turdus falcklandii), fire-eyed diucon (Xolmis pyrope), Patagonian Sierra-finch (Phrygilus patagonicus), tufted tit-tyrant (Anairetes parulus), and thorntailed rayadito (Aphrastura spinicauda). Some mammals, however, may also disperse both species, particularly foxes (Brunner et al. 1976, Jaksic et al. 1980).

To assess whether observation-suggested differences are statistically significant, I sampled two plots for interspecific associations between Rubus and Aristotelia and between Rubus and the most common dry-fruiting tree -Lomatia hirsuta (Lam.) Diels (Proteaceae, hereafter Lomatia). If the main cause of different degrees of interspecific associations is seed dispersal facilitation via shared attraction for seed dispersing birds, Rubus should be more often found under fleshy-fruited Aristotelia than under dry-fruited Lomatia. Additionally, because Aristotelia is a subdioecious tree (populations are composed of hermaphroditic, female and male individuals), I expected that more Rubus individuals would be under fruiting (female or hermaphrodite) individuals of Aristotelia. However, if there are some other more important factors making Aristotelia more attractive for birds (e.g., better cover or perches), or microhabitats beneath Aristotelia are simply more conductive to seedling establishment than beneath Lomatia, there should not be any significant difference in Rubus frequency under fruiting and non-fruiting individuals of Aristotelia. Therefore, I asked two questions: (1) Is Rubus significantly more common under Aristotelia compared with the most common dry-fruiting tree species -Lomatia? (2) Is Rubus significantly more common under female/hermaphroditic (fruiting) than under male (nonfruiting) individuals of Aristotelia?

\section{MATERIAL AND METHODS}

\section{STUDY AREA AND SPECIES}

Two plots (A and B), $600 \mathrm{~m}$ apart, each approximately $200 \mathrm{x}$ $500 \mathrm{~m}$ (10 ha), on SE facing slopes of Cerro Carhuello located between the lakes Villarrica and Caburga, La Araucania, Chile (A: 39 $15^{\circ}$ '07.87'S and $71^{\circ} 52^{\prime} 13.31^{\prime \prime} \mathrm{W}, 326 \mathrm{~m}$ a.s.1.; B: 39 $15^{\prime} 20.45^{\prime \prime} \mathrm{S}$ and $71^{\circ} 52^{\prime} 43.29^{\prime \prime} \mathrm{W}, 447 \mathrm{~m}$ a.s.1.), were sampled during the second half of January and first half of February in 2011 (A) and 2013 (B). Both areas are active or recently abandoned cattle pastures created after logging of Nothofagus forests. Current cover of woody vegetation is approximately $30 \%$.

The focal species of this study was invasive Rubus praecox Bertol., a shrub native to Europe. This species is closely related to $R$. armeniacus Focke that is the most common invasive Rubus species along the Pacific coast of North America (Baldwin 2012). In South America, $R$. praecox has been often misidentified and incorrectly called Rubus ulmifolius Schott or R. constrictus Mull. \& Lefevre (Oberdorfer 1960, Gajardo 1995, Fuentes et al. 2010). Critical morphological attributes of these four species can be found in Weber (1995), Monasterio-Huelin \& Weber (1996), and Zielinski (2004). The major morphological differences are summarized in Appendix A.

The two focal trees in both study areas were fleshyfruiting Aristotelia chilensis and dry-fruiting Lomatia hirsuta. A. chilensis has been treated as dioecious in most of the publications (e.g., Rodríguez et al. 1983, Montenegro 2002, Valdivia \& Simonetti 2007, Gut 2008). However, based on Rodríguez et al. (2005), it seems that A. chilensis is subdioecious (populations are composed of hermaphroditic, female and male individuals, i.e., trioecious sensu Dellaporta \& Calderón-Urrea 1993). In this study, mature non-fruiting trees were assumed to be males. In both plots, these two species were an order of magnitude more common than other fleshy-fruiting (e.g., Fuchsia magellanica Lam., Luma apiculata (DC.) 
Burret, Persea lingue (Ruiz et Pavon) Nees, Rhaphithamnus spinosus (A.L. Juss.) Mold.) or dry-fruiting (e.g., Caldcluvia paniculata (Cav.) Don, Eucryphia cordifolia Cav., Gevuina avellana Molina., Laureliopsis philippiana (Looser) Scodde, Lomatia ferruginea (Cav.) R.Br., Nothofagus dombeyi (Mirb.) Oerst.) trees. All non-focal trees were approximately the same height as focal trees, only a few isolated individuals of $N$. dombeyi were taller. Phytosociologically, this type of "mantle" vegetation was described as association Rhapithamno spinosiAristotelietum chilensis Oberdorfer 1960 (Oberdorfer 1960, Amigo et al. 2007). Open areas that were sampled were grasslands dominated by non-native Agrostis capillaris, A. castellana, Crepis capillaris, Daucus carota, Hypochaeris radicata, Holcus lanatus, Leucanthemum vulgare, Logfia gallica, Lotus pedunculatus (uliginosus), Plantago lanceolata, Prunella vulgaris, Rumex acetosella, Trifolium dubium, T. pratense, Veronica serpillifolia and native Acaena ovalifolia, Centella asiatica, Equisetum bogotense, Leptostigma arnottianum, Nertera granadensis.

SAMPLING AND DATA ANALYSIS

Under each $>2 \mathrm{~m}$ tall Aristotelia or Lomatia tree, a circular plot, with the radius corresponding to the extent of branches that could potentially support birds, was searched for Rubus plants. Rubus presence was only recorded when it rooted within the defined radius. Only sufficiently isolated individuals of Aristotelia and Lomatia, with crown perimeters $>3 \mathrm{~m}$ away from the crown of the nearest Aristotelia or Lomatia were selected. For each tree-centered plot, one reference circular plot of the same radius (i.e., an "open area" plot) was located in a random direction $3 \mathrm{~m}$ away from the tree crown, and analyzed in the same way for Rubus presence. If the randomly located plot was situated under a canopy of another tree, a new random direction was chosen.

Because Aristotelia is semidioecious, the data on frequency (presence/absence) of Rubus plants in analyzed plots were summarized into $2 \times 2$ contingency tables and the null hypotheses of Aristotelia male-Rubus and Aristotelia female/hermaphrodite-Rubus spatial independence were tested separately using the $\mathrm{X}^{2}$ test. The strength of interspecific association was measured as Q (Pielou 1977). The coefficient $\mathrm{Q}$ is equal to -1 when at least one of the two species is never present together with the other one (complete negative association), and is equal to +1 when at least one of the two species is always present together with the other one (complete positive association). The same test and association coefficient were used for assessment of Lomatia-Rubus associations. The square root of $\mathrm{X}^{2}$ method was used for combining of information from several $2 \times 2$ tables (Everitt 1992).

\section{RESULTS}

Invasive Rubus was substantially more common under both focal tree species than in open grasslands (Tables I \& II). The null hypothesis, Aristotelia male-Rubus and Aristotelia female/hermaphrodite-Rubus spatial independence, can be rejected for both sexual modes in both sampled areas $(\mathrm{p}<0.0001$; see Tables I \& II for a summary of frequency data). Also, it is clear that Rubus is associated more strongly (in terms of $\mathrm{Q}$ values and $\mathrm{X}^{2}$ significance) with female/ hermaphrodite (fleshy-fruiting) Aristotelia than with dryfruiting Lomatia in this landscape. Additionally, the frequency of Rubus was higher under Aristotelia female/hermaphrodite trees. However, when tested as Rubus present/absent under Aristotelia male vs. Aristotelia female/hermaphrodite, this tendency was positive in both areas $(\mathrm{Q}=+0.40$ and +0.41$)$, but statistically significant in only in area A because of the relatively low total number of observations in area $\mathrm{B}$ (Table III). When the square root of $\mathrm{X}^{2}$ method was used to combine information from areas A and B (Everitt 1992, p. 25), the resulting $Z=3.025$ was highly significant $(\mathrm{p}<$ 0.002 ), suggesting again that Rubus is strongly associated with female/hermaphrodite Aristotelia trees.

TABLE I. Two by two contingency tables summarizing frequency (presence/absence) of Rubus praecox plants under isolated fruiting (female or hermaphroditic) and non-fruiting (male) Aristotelia chilensis and under Lomatia hirsuta in area A.

TABla I. Tablas de contingencia dos por dos que resumen la frecuencia (presencia/ausencia) de las plantas de Rubus praecox bajo individuos aislados de Aristotelia chilensis con fructificación (femeninos o hermafroditas) y sin fructificación (macho) y bajo Lomatia hirsuta en el área A del estudio.

RUBUS PRAECOX

A. CHILENSIS NON-FRUITING

A. CHILENSIS FRUITING

LOMATIA HIRSUTA

\begin{tabular}{|c|c|c|c|c|c|c|}
\hline & Present & Absent* & Present & Absent* & Present & Absent \\
\hline Present & 77 & 3 & 127 & 8 & 11 & 4 \\
\hline \multirow[t]{2}{*}{ Absent } & 34 & 108 & 24 & 143 & 87 & 94 \\
\hline & \multicolumn{2}{|c|}{$\begin{array}{l}\mathrm{X}^{2}=107.01, \mathrm{p}<0.0001 \\
\mathrm{Q}=+0.97 \quad(\mathrm{n}=222)\end{array}$} & \multicolumn{2}{|c|}{$\begin{array}{l}\mathrm{X}^{2}=189.69, \mathrm{p}<0.0001 \\
\mathrm{Q}=+0.98 \quad(\mathrm{n}=302)\end{array}$} & $\begin{array}{l}X^{2}=3.5 \\
Q=+0.4\end{array}$ & \\
\hline
\end{tabular}

*No fruiting or non-fruiting $A$. chilensis present. 
Gayana Bot. 72(1), 2015

TABLE II. Two by two contingency tables summarizing frequency (presence/absence) of Rubus praecox plants under isolated fruiting (female or hermaphroditic) and non-fruiting (male) Aristotelia chilensis and under Lomatia hirsuta in area B.

TABla II. Tablas de contingencia de dos por dos que resumen la frecuencia (presencia/ausencia) de las plantas de Rubus praecox bajo individuos aislados de Aristotelia chilensis con fructificación (femeninos o hermafroditas) y sin fructificación (machos) y bajo Lomatia hirsuta en el área B de este estudio.

\begin{tabular}{|c|c|c|c|c|c|c|}
\hline RUBUS PRAECOX & \multicolumn{2}{|c|}{ A. CHILENSIS NON-FRUITING } & \multicolumn{2}{|c|}{ A. CHILENSIS FRUITING } & \multicolumn{2}{|c|}{ LOMATIA HIRSUTA } \\
\hline & Present & Absent* & Present & Absent* & Present & Absent \\
\hline Present & 28 & 7 & 42 & 10 & 23 & 9 \\
\hline \multirow[t]{2}{*}{ Absent } & 8 & 29 & 5 & 37 & 123 & 137 \\
\hline & \multicolumn{2}{|c|}{$\begin{array}{l}\mathrm{X}^{2}=24.52, \mathrm{p}<0.0001 \\
\mathrm{Q}=+0.87 \quad(\mathrm{n}=72)\end{array}$} & \multicolumn{2}{|c|}{$\begin{array}{l}\mathrm{X}^{2}=44.07 \mathrm{p}<0.0001 \\
\mathrm{Q}=+0.94 \quad(\mathrm{n}=94)\end{array}$} & \multicolumn{2}{|c|}{$\begin{array}{l}\mathrm{X}^{2}=6.88, \mathrm{p}=0.0087 \\
\mathrm{Q}=+0.48 \quad(\mathrm{n}=292)\end{array}$} \\
\hline
\end{tabular}

*No fruiting or non-fruiting $A$. chilensis present.

\section{DISCUSSION}

The first important conclusion from this study is that invasive Rubus is substantially more common under both focal tree species than in open grasslands (Tables I, II). Aggregation of trees and shrubs is not surprising and has been observed many times in many different plant communities. Several facilitation mechanisms can be responsible for this phenomenon. Nurse effects of trees on shrubs via microclimate or soil modifications have been described in many studies (e.g., Slocum 2001, Calloway 2007, Smith \& Verwijmeren 2011). Nevertheless, immediately, we have to deal with the following question: which was there first, shrub or tree? Shrubs, particularly thorny shrubs, may facilitate establishment of grazing-prone tree seedlings (Hamer et al. 2010, Smith \& Verwijmeren 2011). On the other hand, more frequent establishment of shrubby species under perching/feeding suitable trees may be a result of increased propagule pressure under such trees. In particular, trees providing fleshy fruits for birds may be foci for fleshy-fruited shrub establishment. Whether the first mechanism (facilitation of tree seedling establishment by shrubs) contributed to tree-Rubus associations is impossible to deduce from the collected data. However, the collected data provide strong evidence for the second mechanism (seed dispersal facilitation). Obviously, to different degrees, trees provide perching and/or cover opportunities for birds (Wunderle 1997, Slocum 2001).

The second important conclusion is that while populations of Aristotelia and Lomatia are spatially mixed, Rubus is more often under the first species irrespective of its sexuality mode (Tables I, II). A similar pattern was observed in the Sonoran Desert, where comparison between fleshy-fruited Celtis pallida and non-fleshy-fruited Prosopis vellutina showed that approximately twice as many bird-dispersed seeds of Capsicum annuum var. glabriusculum arrived under Celtis pallida (Carlo $\&$ Tewksbury 2014). Therefore, returning to the first question, it could be inferred that fleshy-fruiting Aristotelia often comes first and fleshy-fruiting Rubus appeared later due to the seed dispersal facilitation. If, on the other hand, establishment of tree species is facilitated by Rubus presence, there should not be any difference in the strength of Lomatia-Rubus and AristoteliaRubus associations. Instead, Q values differed considerably, at $<0.5$ for the first pair and $>0.85$ for the second (Tables I $\&$ II). We may still speculate that perhaps Lomatia seedlings are less dependent on nursing by Rubus, or that microhabitats under Aristotelia are more suitable for establishment of Rubus seedlings. The third conclusion (below) shades more light on the question of what is the principal driver of the discerned associations.

The third conclusion is that there is a higher frequency of Rubus plants under female/hermaphrodite compared to male Aristotelia trees (Tables I, II, III). This result strongly supports the hypothesis that higher Rubus frequency under Aristotelia is primarily due to dispersal facilitation. Nevertheless, some contribution of Rubus seedling facilitation via more suitable microhabitats under Aristotelia trees can't be excluded. A substantially larger frequency of Rubus under male Aristotelia than under Lomatia deserves some attention. It seems that not only presence of fruits, but also tree morphology of Aristotelia serves as a clue for birds when selecting trees for perching/ foraging. Surprisingly, there have been only a very few studies of a gender effect on dispersal facilitation. So far, sex-biased dispersal facilitation has been observed in two pairs of native plant species: Juniperus sabina $+J$. communis (Verdu \& García-Fayos 2003), Cecropia schreberiana + Phoradendron hexastchum (Carlo \& Aukema 2005). Additionally, the recent study by Begnini and Castellani (2013) clearly showed that the female trees of Myrsine coriacea accumulated a greater number of diaspores and seed richness than male trees. At the same time, the male trees of Myrsine accumulated a higher number of seeds and species than areas without trees.

Negative effects of Rubus armeniacus (a closely related 
TABLE III. Two by two contingency table summarizing frequency (presence/absence) of Rubus praecox plants under fruiting (female or hermaphroditic) and non-fruiting (male) Aristotelia chilensis in areas A and B.

TABLA III. Tablas de contingencia de dos por dos que resumen la frecuencia (presencia/ausencia) de las plantas de Rubus praecox bajo individuos aislados de Aristotelia chilensis con fructificación (femeninos o hermafroditas) y sin fructificación (machos) y bajo Lomatia hirsuta en las áreas A y B de este estudio.

\begin{tabular}{|c|c|c|c|c|c|}
\hline & & \multicolumn{4}{|c|}{ ARISTOTELIA CHILENSIS } \\
\hline & & \multicolumn{2}{|c|}{ Area A } & \multicolumn{2}{|c|}{ Area B } \\
\hline & & NON-FRUITING & FRUITING & NON-FRUITING & FRUITING \\
\hline \multirow[t]{3}{*}{ RUBUS PRAECOX } & Present & 77 & 127 & 28 & 42 \\
\hline & Absent & 34 & 24 & 8 & 5 \\
\hline & & \multicolumn{2}{|c|}{$\begin{array}{l}\mathrm{X}^{2}=8.06, \quad \mathrm{P}=0.0045 \\
\mathrm{Q}=+0.40 \quad(\mathrm{~N}=262)\end{array}$} & \multicolumn{2}{|c|}{$\begin{array}{l}X^{2}=2.07, \quad P=0.15 \\
Q=+0.41 \quad(N=83)\end{array}$} \\
\hline
\end{tabular}

species to $R$. praecox) on native plants and wildlife are well known (Caplan \& Yeakley 2006, Williams et al. 2006, Astley 2010). Obviously, dispersal facilitation of an already widespread invasive shrub by a widespread native fleshy-fruited tree is a major challenge for farmers and managers of protected areas. Control/eradication of a major dispersal agent in some valuable and spatially limited protected areas represents one option (e.g., control of Turdus falcklandii in the Juan Fernandez Archipelago where both Aristotelia and Rubus ? ulmifolius are non-native; Smith-Ramírez et al. 2013). Otherwise, besides endless investments into mechanical and/or chemical control, speciesspecific biological control may be the only alternative (Mazzolari et al. 2011, Morin \& Evans 2012). While there is already some experience with biological control of Rubus spp. in Australia, this may only be of a limited help, because, surprisingly, neither $R$. praecox nor $R$. armeniacus has been found in Australia so far (Evans et al. 2007, Rejmánek \& Richardson 2013).

\section{ACKNOWLEDGEMENTS}

Clare Aslan, Aníbal Pauchard, Bohumil Travníček and two anonymous referees made many important comments on the previous versions of this paper. This project was partially supporter by the University of California Agricultural Experiment Station.

\section{REFERENCES}

Amigo, J., C. Ramírez \& L.G. Quintanilla. 2007. Mantle communities of the temperate woodlands of South Central Chile: a phytosociological study of the order Aristotelietalia chilensis. Phytocoenologia 37: 269-319.

Astley, C. 2010. How does Himalayan blackberry (Rubus armeniacus) impact breeding bird diversity? A case study of the lower mainland of British Columbia. MS Thesis, Royal
Roads University, Victoria, BC. 56 pp.

BALdwin, B.G. (Ed.) 2012. The Jepson Manual - Vascular Plants of California. 2nd ed., University of California Press, Berkeley. $1568 \mathrm{pp}$

Begnini, R.M. \& T.T. CASTELlani. 2013. Seed rain under the canopies of female and male Myrsine coriacea, a pioneer tree from Brazilian Atlantic forest. Journal of Tropical Ecology 29: 391-399.

Bernes, D.G., N. Farwig, G. Schaab \& K. Bohning-Gaese. 2008. Exotic guavas are foci of forest regeneration in Kenyan farmland. Biotropica 40: 104-112.

BRonstein, J.L. 2009. The evolution of facilitation and mutualism. Journal of Ecology 97: 1160-1170.

Brunner, H., R.V. Harris \& R.L. Amor. 1976. A note on the dispersal of seeds of blackberry (Rubus procerus P.J.Muell.) by foxes and emus. Weed Research 16: 171-173.

Calloway, R.M. 2007. Positive Interactions and Interdependence in Plant Communities. Springer, Dordrecht. 415 pp.

CAPlan, J.S. \& J.A. Yeakley. 2006. Rubus armeniacus (Himalayan blackberry) occurrence and growth in relation to soil and light condition in western Oregon. Northwest Science 80: 9-17.

CARLO, T.A. 2005. Interspecific neighbors change seed dispersal pattern of an avian-dispersed plant. Ecology 86: 2440-2449.

Carlo, T.A. \& J.E. Aukema. 2005. Female-directed dispersal and facilitation between a tropical mistletoe and a deciduous host. Ecology 86: 3245-3251.

CARLo, T.A. \& J.J. TeWKSBURy. 2014. Directness and tempo of avian seed dispersal increases emergence of wild chiltepins in desert grasslands. Journal of Ecology 102: 248-255.

Cavieres, L.A., C.L. Quiroz \& M.A. Molina-Montenegro. 2008. Facilitation of the non-native Taraxacum officinale by native nurse cushion species in the high Andes of central Chile: are there differences between nurses? Functional Ecology 22: 148-156.

Clark, C.J., J.R. Poulsen, E.F. Connor \& V.T. Parker. 2004. Fruiting trees as dispersal foci in a semi-deciduous tropical forest. Oecologia 139: 66-75.

Dellaporta, S.L. \& A. Calderón-Urrea. 1993. Sex determination in flowering plants. The Plant Cell 5: 1241-1251. 
Evans, K.J., D.E. Symon, M.A. Whalen, J.R. Hosking, R.M. Barker \& J.A. Oliver. 2007. Systematics of the Rubus fruticosus aggregate (Rosaceae) and other exotic Rubus taxa in Australia. Australian Systematic Botany 20: 187-251.

Everitt, B.S. 1992. The Analysis of Contingency Tables. 2nd ed., Chapmann \& Hall, London. 164 pp.

FLORY, S.L. \& J.T. BAUER. 2014. Experimental evidence for indirect facilitation among invasive plants. Journal of Ecology 102: 12-18.

Foster, J.T. \& S.K. Robinson. 2007. Introduced birds and the fate of Hawaiian rainforests. Conservation Biology 21: 1248-1257.

Foxcroft, L.C. \& M. Rejmánek. 2007. What helps Opuntia stricta invade Kruger National Park, South Africa: Baboon or elephants? Applied Vegetation Science 10: 265-270.

Fuentes, N., E. Ugarte, I. KüHn \& S. Klotz. 2010. Alien plants in southern South America. A framework for evaluation and management of mutual risk of invasion between Chile and Argentina. Biological Invasions 12: 3227-3236.

GAJARDO, R. 1995. La vegetación natural de Chile. 2nd ed., Editorial Universitaria, Santiago de Chile. 165 pp.

Garcia, D., I. Martinez \& J.R. Obeso. 2007. Seed transfer among bird-dispersed trees and its consequences for post-dispersal seed fate. Basic and Applied Ecology 8: 533-543.

Gut, B. 2008. Trees of Patagonia. Birkhäuser, Basel, Switzerland. $283 \mathrm{pp}$.

Hamer, R., A. Kiewitt, G. Morgan \& R. Gill. 2010. Does the development of bramble (Rubus fruticosus L. agg.) facilitated the growth and establishment of tree seedlings in woodland by reducing deer browsing damage? Forestry 83 : 93-102.

Jaksic, F.M., R.P. Schlatter \& J.L. Yanez. 1980. Feeding ecology of central Chilean foxes, Dusicyon culpeus and Dusicyon oriseus. Journal of Mammaliology 61: 254-260.

Madrigal-Gonzales, J., A.P. Cea \& L. SÁnchez-Fernández. 2013. Facilitation of the non-native annual plant Mesembryanthemum crystalinum (Aizoaceae) by the endemic cactus Eulychnia acida (Cactaceae) in the Atacama Desert. Biological Invasions 15: 1439-1447.

Maron, J.L. \& P.G. ConNors. 1996. A native nitrogen-fixing shrub facilitates weed invasion. Oecologia 105: 302-312.

Mazzolari, A.C., V.M. Comparatore \& F. Bedmar. 2011. Control of elmleaf blackberry invasion in a natural reserve in Argentina. Journal for Nature Conservation 19: 185-191.

Monasterio-Huelin, E. \& H.E. Weber. 1996. Taxonomy and nomenclature of Rubus ulmifolius and Rubus sanctus (Rosaceae). Edinburgh Journal of Botany 53: 311-322.

Montenegro, G. 2002. Chile nuestra flora útil. 2a ed. Pontificia Universidad Católica de Chile, Santiago, Chile. 265 pp.

Morin, L. \& K.J. Evans. 2012. Rubus fruticosus L. aggregate European blackberry. In: M. Julien, R. McFadyen \& J. Cullen (eds.), Biological Control of Weeds in Australia. CSIRO, Collingwood, p. 499-509.

Neilan, W., C.P. Catterall, J. Kanowski \& S. Mockenna. 2006. Do frugivorous birds assist rainforest succession in weed dominated old-field regrowth of subtropical Australia? Biological Conservation 129: 393-407.

Oberdorfer, E. 1960. Pflanzenzoziologische Studien in Chile. Verlag von J. Cramer, Weinheim. 208 pp.

Pielou, E.C. 1977. Mathematical Ecology. Wiley, New York. 385 pp.

Pyšek, P., D.M. Richardson, M. Rejmánek, G.L. Webster, M.
Williamson \& J. KirSChner. 2004. Alien plants in checklists and floras: towards better communication between taxonomists and ecologists. Taxon 53: 131-143.

RejmáneK, M. \& D.M. Richardson. 2013. Trees and shrubs as invasive alien species - 2013 update of the global database. Diversity and Distributions 19: 1093-1094.

Rejmánek, M., D.M. Richardson \& P. Pyšek. 2013. Plant invasions and invasibility of plant communities. In: E. van der Maarel \& J. Franklin, eds. Vegetation Ecology, 2nd ed., Wiley, pp. 387-424.

Richardson, D.M., P. Pyšek, M. Rejmánek, M.G. Barbour, F.D. PANeTta \& C.J. West. 2000. Naturalization and invasion of alien plants: concepts and definitions. Diversity and Distributions 6: 93-107.

Rodríguez R., O. Mathei \& M. Quezada. 1983. Flora arbórea de Chile. Universidad de Concepción, Concepción, Chile.

Rodríguez, R., E. Ruíz \& J.P. Elissetche. 2005. Árboles en Chile. Universidad de Concepción, Concepción, Chile.

Simberloff, D. \& M. Rejmánek (Eds.). 2011. Encyclopedia of Biological Invasions. University of California Press, Berkeley. 765 pp.

SLocum, M.G. 2001. How tree species differ as recruitment foci in a tropical pasture. Ecology 82: 2547-2559.

Smith, C. \& M. Verwijmeren. 2011. Tree-shrub associations in grazed woodlands: first rodents, than cattle? Plant Ecology 212: 483-493.

Smith-Ramírez, C., G. Arellano, E. Hagen, R. Vargas, J. Castillo \& A. Miranda. 2013. El rol de Turdus falcklandii (Aves: Passeriforme) como dispersor de plantas invasoras en el archipiélago de Juan Fernández. Revista Chilena de Historia Natural 86: 33-48.

Tecco, P.A., S. Diaz, D.E. Gurvich, N. Pérez-Hardguindeguy, M. CABIDo \& G.A. Bertone. 2007. Facilitation and interference underlying the association between the woody invaders Pyracantha angustifolia and Ligustrum lucidum. Applied Vegetation Science 10: 211-218.

Tecco, P.A., D.E. Gurvich, S. Díaz, N. Pérez-Harguindeguy \& M. CABIDO. 2006. Positive interaction between invasive plants: The influence of Pyracantha angustifolia on the recruitment of native and exotic woody species. Austral Ecology 31: 293-300.

Valdivia, C.E. \& J.A. SimonetTi. 2007. Decreased frugivory and seed germination rate do not reduce seedling recruitment rates of Aristotelia chilensis in a fragmented forest. Biodiversity and Conservation 16: 1593-1602.

Verdu, M. \& P. Garcia-Fayos. 2003. Frugivorous birds mediate sex-biased facilitation in a dioecious nurse plant. Journal of Vegetation Science 14: 35-42.

Vieira, I.C.G., C. Uhl \& D. Nepstad. 1994. The role of the shrub Cordia multispicata Cham. as a succession facilitator in an abandoned pasture in Paragominas, Amazonia. Vegetatio 115 91-99.

Von Zeipel, H. \& O. EriKsson. 2007. Fruit removal in the forest herb Actaea spicata depends on local context of fruits sharing the same dispersers. International Journal of Plant Sciences 168: 855-860.

WeBER, H.E. 1995. Rubus L. In: G. Hegi (eds.). Illustrierte Flora von Mitteleuropa. 4(2A): 284-595. Blackwell WissenschaftsVerlag, Berlin.

White, E. \& G. Vivian-Smith. 2011. Contagious dispersal of seeds of synchronously fruiting species beneath invasive and 
native fleshy-fruited trees. Austral Ecology 36: 195-202.

Williams, K., L.J. Westrick \& B.J. Williams. 2006. Effects of blackberry (Rubus discolor) invasion on oak population dynamics in a California savanna. Forest Ecology and Management 228: 187-196.
Wunderle, J.M. 1997. The role of animal seed dispersal in accelerating native forest regeneration on degraded tropical land. Forest Ecology and Management 99: 223-235.

Zielinski, J. 2004. The genus Rubus (Rosaceae) in Poland. Polish Botanical studies 16: 1-300.

Appendix A. Attributes of Rubus praecox, $R$. constrictus and $R$. ulmifolius. Apéndice A. Atributos de Rubus praecox, R. constrictus y R. ulmifolius.

\begin{tabular}{|c|c|c|c|c|}
\hline & FIRST-YEAR STEMS & $\begin{array}{l}\text { PRICKLES ON } \\
\text { FIRST-YEAR STEMS }\end{array}$ & $\begin{array}{l}\text { SEPALS \& LEAVES BENEATH } \\
\text { ON FIRST-YEAR STEMS }\end{array}$ & INFLORESCENCE AXIS \\
\hline $\begin{array}{l}\text { R. praecox } \\
\text { Bertol. }\end{array}$ & $\begin{array}{l}\text { not glaucous, } \\
\text { angled to furrowed }\end{array}$ & $\begin{array}{l}\text { straight, usually slightly } \\
\text { declining or slightly curved, } \\
\text { colored like stem (green or } \\
\text { dark violet)*, } 7-11 \mathrm{~mm}\end{array}$ & $\begin{array}{l}\text { greyish-green, } \\
\text { terminal leaflets } \\
\text { ovate to broadly elliptic }\end{array}$ & $\begin{array}{l}\text { with greyish, mixed (stellate, } \\
\text { tufted and simple long) hairs } \\
\text { and strong curved prickles* }\end{array}$ \\
\hline $\begin{array}{l}\text { R. constrictus } \\
\text { P.J. Mull. \& Lefevre }\end{array}$ & $\begin{array}{l}\text { not glaucous, } \\
\text { deeply furrowed }\end{array}$ & $\begin{array}{l}\text { distinctly curved, } \\
\text { stout-based, } \\
6-7 \mathrm{~mm} \text { long }\end{array}$ & $\begin{array}{l}\text { indistinctly grey-white } \\
\text { felted (but with many } \\
\text { simple hairs) }\end{array}$ & $\begin{array}{l}\text { with tufted and simple long } \\
\text { hairs and small curved } \\
\text { prickles }\end{array}$ \\
\hline $\begin{array}{l}\text { R. ulmifolius } \\
\text { Schott } \\
\text { (syn.: R. discolor }\end{array}$ & $\begin{array}{l}\text { glaucous**, } \\
\text { slightly furrowed }\end{array}$ & $\begin{array}{l}\text { straight or curved, } \\
6-10 \mathrm{~mm} \text { long, } \\
\text { broad-based } * * *\end{array}$ & $\begin{array}{l}\text { grey-white felted, } \\
\text { terminal leaflets oblong } \\
\text { to narrow-obovate }\end{array}$ & $\begin{array}{l}\text { with whitish-felted hairs, } \\
\pm \text { without long simple hairs, } \\
\text { and with variable prickles }\end{array}$ \\
\hline
\end{tabular}

*Closely related $R$. armeniacus Focke has straight prickles on the inflorescence axis; prickles on the first-year stems are red at the base, with yellowish points. **Young shoots violet-red, white scaly covering on old stems. ***Prickles missing in R. ulmifolius var. anoplothyrus Sudre. Petals of $R$. praecox are white or pale pink, petals of $R$. constrictus are white, and petals of $R$. ulmifolius are mostly pink, rarely white. $R$. praecox has largest fruits $(1.4$ to $2.1 \mathrm{~cm})$ among the three species compared here. $R$. ulmifolius is the most variable of the three species because of its sexual reproduction. The other two species behave mostly as apomicts. Based on Weber (1995), Monasterio-Huelin \& Weber (1996), Evans \& Weber 2003, Zielinski (2004), B. Travníček (personal communication, June 2014), and examination of herbarium specimens. (PRM, UC, DAV). Voucher specimens of R. praecox from the investigated area are deposited in the herbarium of the University of California - Davis (DAV). / * Rubus armeniacus Focke, cercanamente relacionado, tiene espinas rectas en el eje de la inflorescencia; las espinas en los tallos del primer año son rojas en la base, con puntos de color amarillento. ** Brotes jóvenes de color violeta-rojo, con cubierta escamosa blanca en los tallos viejos. *** Espinas no presentes en $R$. ulmifolius var. anoplothyrus Sudre. Pétalos de $R$. praecox son de color blanco o rosa pálido, pétalos de $R$. constrictus son de color blanco y los pétalos de $R$. ulmifolius son en su mayoría de color rosado, raramente blanco. Entre las tres especies aquí comparadas $R$. praecox tiene los frutos más grandes $(1,4 \mathrm{a} 2,1 \mathrm{~cm})$. R. ulmifolius es el más variable de las tres especies, debido a su reproducción sexual. Las otras dos especies se comportan principalmente como apomícticas. Basado en Weber (1995), Monasterio-Huelin\& Weber (1996), Evans \& Weber 2003, Zielinski (2004), B. Trávníček (comunicación personal, junio de 2014), y el examen de especímenes de herbario (PRM, UC, DAV). Ejemplares de respaldo de $R$. praecox provenientes del área de investigación están depositados en el herbario de la Universidad de California - Davis (DAV).

Recibido: 14.02 .14

Aceptado: 01.08 .14 